\title{
6
}

\section{BREAKING FREE FROM PARTITOCRACY}

\section{Do Belgian candidates stand out?}

\author{
Audrey Vandeleene, Chloé Janssen and \\ Maximilien Cogels
}

\subsection{Introduction}

Belgium is said to be a textbook example of a partitocracy, that is an extreme case of dominance of political parties on all aspects of the social and political system (Dewachter 2002; De Winter, della Porta, and Deschouwer 1996a; Steyvers 2014). This happens through patronage in parliament, public administration, the judiciary, and even in civil society (de Visscher 2004; De Winter 2002; De Winter and Dumont 2000, 2006). Hence, one can assert that Belgian exceptionalism resides among others in her strong partitocratic nature. Belgian parties are powerful actors, if not the most powerful actors of the system (De Winter, della Porta, and Deschouwer 1996b). But is it exceptional compared to other partitocratic countries?

Scholars point at the decreasing legitimacy of the partitocratic system, and of political parties in general (Mair 2013; Rahat and Kenig 2018), as attested by declining trends in party membership (van Haute et al. 2013), higher levels of electoral volatility (Dassonneville 2018), and the rise of parties with renewed organizational structures or ideology (Hobolt and Tilley 2016; Mazzoleni and Voerman 2016). One may then wonder whether these weakened party organizations still manage to hold a strong control on their representatives or if politicians are nowadays more often allowed to break with their party line. Building on the (contested) personalization thesis (Balmas et al. 2014; Karvonen 2010), this chapter proposes to disentangle parties' grip on a particular group of political elites, the candidates to elected office.

Candidates are key political actors, first during the campaign, then as representatives once elected (André et al. 2017). Electoral candidates embody the party (Katz 2001) from the moment they have been officially selected by party selectorates (Hazan and Rahat 2010). Yet this is not to presume that candidates 
are left loose in the wilderness, free of their acts and speech. What we want to unpack in this chapter is the extent to which candidates report being free from their party grip, to highlight the exceptional nature of Belgian partitocracy. This chapter assesses the leeway let to Belgian candidates in terms of campaigning and representational style compared to three other partitocratic regimes: Italy, Greece, and Portugal. We conduct our research using the large longitudinal data set of the Comparative Candidate Survey (CCS).

We proceed as follows. The first section reflects on the candidate-party linkage and presents our research question: (when) do candidates in partitocratic regimes break free from their party? We then build several hypotheses based on the literature. Thereafter, we present our large data set and discuss the operationalization of our variables. We continue with a comparative descriptive analysis across countries before studying the determinants of Belgian candidates' independence more specifically in a multivariate fashion. We conclude by discussing Belgium's presumed exceptionalism regarding its partitocratic nature.

\subsection{Theoretical framework}

It has been demonstrated that the idealistic view of a political party as a unitary actor does not hold (Tavits 2009). Parties strive to reach and maintain cohesion but they remain a collection of individuals, be them MPs, party members, or electoral candidates, who may sometimes be hard to discipline (Carey 2007). To avoid disunity, parties may ask their folks to sign a pledge where they commit to the party ideology and rules, for instance, a charter for members to sign upon reception of their party card, or when selected as candidates (Aylott, Blomgren, and Bergman 2013; Cordero and Coller 2015; Gauja 2010).

But still, party headquarters cannot avoid individualistic behaviors from their candidates. At campaign time, candidates meet "potential voters face-toface on market squares, through visits to companies, at social events, or simply through knocking on their front doors" (Zittel and Gschwend 2008, 978). Parties simply cannot control whether all candidates stay neatly on the party line. Nonetheless, candidates might have incentives to follow the party line to fulfill their political ambitions. Different goals mark politicians' parliamentary career. In this regard, (re)selection and (re)election are crucial because they directly pave their way to elected assemblies (Hazan 2014; Strøm 1997). These goals shape to some extent candidates' incentives to please (or not) the party leadership. Hence, the question we ask is: (when) do candidates in partitocratic regimes break free from their party?

Primary explanations for candidates' role conception have been found in macro-level variables and notably the electoral system (Zittel and Gschwend 2008). The latter strongly determines the incentives for candidates to cultivate a personal vote (Carey and Shugart 1995). For instance, contexts of intraparty competition where candidates need to distinguish themselves from their co-partisans to get elected generate greater incentives for candidates to play the 
personal rather than the party card toward voters. Since electoral success can be measured individually, candidates will make their best to garner the most personal votes.

The Belgian electoral system both hinders and stimulates candidates' independence toward their party. On the one hand, the flexible list system is nor a candidate nor a party-centered system. Contrary to single-member district (SMD) systems where a single candidacy per party per district puts these at the forefront as the sole figure of the party (Grofman 2005), group-based behaviors are more common in list systems. But on the other hand, the preferential voting system allows voters to assess candidates on an individual basis (Zittel and Gschwend 2008). Belgian voters can convey an individual preference for one or several candidates, which encourages candidates to cultivate a personal vote as opposed to PR closed list systems where candidates are assessed en bloc (Carey 2007; Cordero and Coller 2015).

However, scholars report that macro-level variables do not have a causal effect on candidates' independence toward their party but form the setting allowing candidates to break more or less free from it (Zittel and Gschwend 2008). Candidates' independence is rather determined by parties' or individuals' characteristics. Hence, large variations are expected even within partitocratic regimes.

This chapter investigates the factors affecting candidates' incentives to break free from their party within a partitocratic context. Although our overarching hypothesis is that Belgian candidates stand out in a limited way given the strong party control, we still expect to find differences between candidates based on several party- and individual-level variables.

At the party level, party ideology is expected to favor or hinder candidates' independence and this for two main reasons. First, an ideology encompasses a set of values and principles which may impact candidates' role conception and behavior during the campaign (Close 2018). Second, it often shapes how the party is structured: the dispersion of power within the organization and the degree of freedom let to candidates are likely to vary along with ideology. Regarding values, rightist candidates are expected to cherish the values of individualism and reject any form of regulation, and leftist candidates would favor collectivism and group-based solutions (Coffé and Reiser 2018). Importantly, Close and Nuñez (2016) argue that one cannot reason linearly along the left-right spectrum since major differences have to be pinpointed in the organizational traditions of parties that do not follow this logic. They encourage party families-based studies to investigate party cohesion.

Liberal parties are expected to favor candidates' independence due to their lighter organizations and their lack of strong guidelines (Enyedi and Linek 2008). At the opposite, radical right parties are expected to have very few independent candidates due to their strong hierarchical organizations favoring order and discipline (Mudde 2007). Green parties are said to offer a weakly hierarchical structure and promote values of self-fulfillment and self-affirmation, encouraging 
candidates' independence (Close 2018). Yet their stances against individualism and their collective decision-making mode of functioning downplay the expectation that Green candidates would show independence (Rihoux and Frankland 2008; Talshir 2002). This implies that leftist party families are expected to apply a stronger grip on their candidates, as opposed to rightist families, with the exception of the radical right parties. Our first hypothesis therefore stipulates that:

H1: Candidates are more likely to break free from their party in rightist party families, except for radical right families.

A second party-factor refers to candidate selection procedure. Considering that candidates aim to get (re)selected (Strøm 1997), they need to please the selectorate (i.e. those who decide who gets selected). In a partitocratic context, we expect party headquarters not to value independent lone wolves but rather to prefer group-players who they can easily coordinate (Hazan 2014). Accordingly, when candidate selection is organized at the central party level (e.g. the party board), candidates would have stronger incentives to play collective than when the decisions are taken at the constituency level where party selectorates would not be able to ensure party discipline as much (Cordero and Coller 2015; Zittel and Gschwend 2008). In the same vein, candidate selection procedures involving many selectors, i.e. inclusive selectorates, are expected to stimulate candidates' independence, as opposed to exclusive selectorates (a small group of selectors like a list committee) who are more able to guarantee cohesion and discipline (Key 1964; Kristjánsson 1998). Building up on this, we hypothesize that:

$\mathrm{H} 2$ : Candidates are more likely to break free from their party when candidate selection procedures are decentralized and inclusive.

Third, the size of the party in the constituency is likely to influence candidates' independence from their party. In constituencies with a large district magnitude (i.e. the number of seats at stake in the district), candidates face many contenders within their party and party magnitudes (i.e. the number of seats won by the party) are likely to be higher. As Renwick and Pilet (2016) indicated, one expects preference votes to be more determinant for candidates' election as party magnitude increases, because the system gets more 'open'. Candidates are therefore more likely to cultivate a personal vote as district (and, thus, party) magnitude increases (Shugart, Valdini, and Suominen 2005). Yet, we know that very few candidates manage to break the rank order in the Belgian national context (Vandeleene, Dodeigne, and De Winter 2016). Nevertheless, beyond determining who is getting elected, attracting a large share of preference votes is a signal to selectorates that the candidate may be entitled to climb the ladder of the electoral list in the next election (André et al. 2017). When party magnitude is smaller, on the contrary, preference votes may signal popularity to the selectorates but are not likely to help candidates be elected. Research has 
demonstrated that when party magnitude is low, voters are less keen on casting a preference vote as opposed to a list vote (André, Wauters, and Pilet 2012). Given the effect of preference votes on candidates' reselection and election, we expect a mechanism according to which when party size in the district increases, the likelihood of receiving preference votes follow suits, as well as the chances that preference votes will boost electoral success. The incentives for candidates to break free from their party are therefore greater when party size is larger. Based on this, we hypothesize that:

H3: Candidates are more likely to break free from their party when party size in the district is large.

Next to party-level variables, we expect independency to be encouraged by individual-level factors, i.e. the characteristics of the candidates themselves. First, their political experience and the subsequent linkage to the party matter. We expect incumbent MPs to be more likely to behave independently from their party. As detailed by Zittel and Gschwend (2008), incumbents can indeed rely on critical resources to organize their campaign, like their personal staff or network. We also expect them to be more confident in their capacities to be popular among voters. On top of that, incumbents are de facto more well-known by voters given their ongoing political career and their access to the media. These elements lead us to assume that incumbents will be keener on playing their individual card.

Yet political experience has not always been flagged as influential in determining independence (Cordero and Coller 2015). Tavits (2009) argues that it is not parliamentary experience that matters but rather local experience. Local incumbents (e.g. mayors) enjoy a strong local base, making them less dependent on the party for their local political career. If they are active at the local level only, they may be less socialized with the functioning of the party at the national level and, henceforth, be less likely to follow the national party's guidelines. In the same line, we may expect incumbent MPs not to deviate from their party rules since they are often themselves part of the party elite and set these rules (Zittel and Gschwend 2008). Hence, although incumbent MPs have the means to break free, they do not per se wish to do so because of a greater sense of loyalty toward their party. This mechanism is likely to be similar for candidates who are involved in the party as an organization. We expect that holding a mandate within the party increases candidates' loyalty and reduces independence. These considerations lead us to a twofold hypothesis covering the party-candidate linkage.

H4a: Candidates are more likely to break free from their party when they hold an elected mandate at the local level.

H4b: Candidates are more likely to break free from their party when they do not hold a party office. 
Electoral popularity and even more electoral security are important incentives for candidates to free themselves from the party. If candidates believe that their chances to get elected are high, they will be more likely to enter in a personal relationship with voters. As argued by Zittel and Gschwend (2008), this would especially be the case when the victory margin is narrow, similar to a horse race "which engages everyone involved to an increasing degree the closer it gets" (p. 984). To mobilize the small percentage of votes who could secure their election, these candidates will behave more independently. At the opposite, when candidates know that the battle is lost, their incentives are rather to be loyal to the party to please the selectorate for reselection.

H5: Candidates on a hopeful list position are more likely to break free from their party.

Finally, we assume that candidates' ideological preferences may also be predictors of their independence. Candidates who are more distant ideologically from their party are expected to be more independent than candidates more in line with the party ideology (Zittel and Gschwend 2008). The loyalty to the party is indeed likely to be influenced by the degree of agreement between the candidates and their party's policy preferences, or the ideological congruence (Lesschaeve 2017).

H6: Candidates are more likely to break free from their party when they are ideologically incongruent with their party.

\subsection{Empirical strategy: data and method}

\subsubsection{The candidate surveys}

Our analyses rely on the CCS, a large international project surveying legislative candidates just after the elections on matters of campaigning, policy issues, representation, or their political and personal background. Extracting a subset of this extensive database, we grouped four partitocratic countries: Belgium, Greece, Italy, and Portugal (De Winter, della Porta, and Deschouwer 1996a). Other countries that could be considered partitocratic (e.g. Spain or Austria) have not been included due to data availability. Our data set covers one election in each country, and 1.789 candidates in total (see Table 6.1).

\subsubsection{Variable operationalization}

\subsubsection{Dependent variable}

To capture the independence of candidates toward their party, we selected three variables accounting for candidates' campaigning and representational style. We propose two dependent variables to measure the former. The first variable 
TABLE 6.1 Number of candidates by country

\begin{tabular}{lcc}
\hline Countries & Election year & Candidates (N) \\
\hline Belgium & 2014 & 665 \\
Greece & 2009 & 195 \\
Italy & 2013 & 672 \\
Portugal & 2011 & 257 \\
\hline
\end{tabular}

concerns the personal campaigning resources (i.e. tools that aim to promote the candidate rather than the party) used by the candidates. This allows us to grasp the extent to which the party allowed the candidate to run a personal campaign. Our variable personal campaign resources has been constructed by taking the sum of the personal campaigning tools used by candidates. This includes personal campaigning posters, personal ads in the newspapers, personal flyers, personal website, and having individual meetings at home or drop-in offices. The variable ranges from 0 (i.e. the candidate did not use any of these tools) to 5 (i.e. the candidate used all of them).

Further than the practice of the campaign, the CCS also asked candidates more theoretically about the primary aim of their campaign. The question takes the form of a scale ranging between 0 (which depicts that candidates wanted to attract as much attention as possible to them selves as candidates) and 10 (which refers to candidates who tried to attract as much attention as possible to their party).

Candidates' representational style is determined based on three questions asking how MPs should vote (1) if their opinion diverges from the opinion of their voters; (2) if the opinion of their voters diverges from their party's position; and (3) if their opinion diverges from their party's position. We built a dichotomous variable where 1 represents the party delegates, i.e. candidates whose choice is to follow the party in any case (Janssen, Chiru, and De Winter 2018).

\subsubsection{Independent variables}

We expect first party-level variables to affect the propensity of candidates to be independent from their party. The variable party ideology has been constructed based on how candidates position their party on the left-right scale. We consider the average position of all candidates from the same party. We added a dummy for the radical right parties, based on the party brand. Second, the degree of inclusiveness of the candidate selection process has been operationalized to keep two categories: exclusive (e.g. party leader) vs. nonexclusive (including nomination by party delegates or all members of the party). For the degree of centralization, we built two categories (centralized for a decision at the party level and decentralized for the constituency level). Third, the party magnitude refers to the number of MPs elected within the 
party list in a given district. This accounts for the size of the party within the district.

We also include individual-level variables. Candidates' local experience is a dummy variable, with 1 indicating that the candidate holds a local office at the moment of the election or held it in the past. The party mandate variable flags candidates who have ever worked for the party (at the local, regional, or national level, for instance, as a chair or a secretary of a party's section). The hopeful list position, a position on the list with high chances of being elected, has been calculated based on the current election $(t)$. It can indeed be argued that most candidates, who were elected in an election, were located on a hopeful list position. We finally measure the ideological congruence between candidates and their party on the 0-10 left-right scale. We computed the absolute difference (own position minus party position) of both scales to create a new variable. A value close to zero means that the candidate and the party are perfectly aligned. In each model, we control for candidates' gender, education (university degree vs. no university degree), and age.

\subsection{Empirical analyses}

\subsubsection{Bivariate analyses: do Belgian candidates stand out?}

Do candidates in partitocratic countries stand out from their party? We aim to compare Belgian candidates to their counterparts in other partitocratic regimes. We start by comparing the means for the first two dependent variables to investigate potential differences in candidates' campaigning style (see Table 6.2).

In Belgium, candidates use on average about three personal campaigning resources, which is relatively similar to Greek candidates. However, the mean is considerably lower in Italy and especially in Portugal. Hence, Belgian (and Greek) candidates tend to be more likely than Italian or Portuguese candidates to promote their own person during the campaign. Differences in the means are significant $(p=0.00)$.

We now turn to the primary aim candidates give to their campaign. The higher the score, the greater their aim to attract attention to the party rather than to themselves. Here, candidates in general assert their aim is to give more

TABLE 6.2 Description of candidates' campaigning style across countries $(\mu(\mathrm{N}))$

\begin{tabular}{lcc}
\hline & Personal campaign resources & Primary aim of campaign \\
\hline Belgium & $3.07(595)$ & $7.18(641)$ \\
Greece & $3.30(175)$ & $5.84(175)$ \\
Italy & $2.17(573)$ & $6.60(651)$ \\
Portugal & $0.92(185)$ & $8.53(188)$ \\
Total & $2.50(1528)$ & $6.96(1655)$ \\
\hline
\end{tabular}


attention to the party (with a general average of 6.96 out of 10). Belgian candidates stand above this general average (7.18) but below Portuguese candidates. While Greek and Belgian candidates had a similar use of campaigning resources, we find stronger differences here as Greek candidates are less likely to assert that the aim of their campaign is to promote the party. Here again, differences across means are significant $(p=0.00)$.

Our third dependent variable is an indicator of candidates' representational style. Table 6.3 shows the distribution of this variable across countries. Belgium is the only country for which the proportion of party delegates (34.8) is greater than the total proportion of party delegates for all countries (26.3). This points that Belgian candidates are more likely to assert that they will follow their party's opinion within parliament than candidates in Greece, Italy, or Portugal. We note that the proportion of party delegates is particularly low in the latter (17.5). Hence, expected party discipline within the parliament appears to be particularly strong in Belgium compared to other countries.

To summarize our descriptive findings, we can say that Belgian candidates do not seem to stand out as such compared to their counterparts in other partitocratic countries when it comes to their campaigning style. However, we see that they strongly differ to other candidates when it comes to their representational style, as they are more likely to act loyally to their party in the deliberative process within parliament.

\subsubsection{Multivariate analyses: (when) do Belgian candidates break free?}

We now focus on the Belgian candidates and build explanatory models to uncover why they may break free from their party. The models depicted in Table 6.4 are based on the dependent variables related to candidates' campaigning style. The first model uses candidates' personal campaign resources as dependent variable while the second uses the primary aim of the campaign. Since the dependent variables are continuous, we ran linear regressions.

Our first model captures the personal focus (vs. party focus) of the campaign resources used by candidates. The underlying assumption is that the more diverse the set of personal campaigning resources, the more likely it is that candidates put

TABLE 6.3 Distribution of party delegates across countries, N (\%)

\begin{tabular}{lcrr}
\hline & \multicolumn{2}{c}{ Party delegates } & \\
\cline { 2 - 3 } & \multicolumn{1}{c}{ No } & \multicolumn{1}{c}{ Yes } & \multicolumn{1}{c}{$N$} \\
\hline Belgium & $302(65.2)$ & $161(34.8)$ & $463(100.0)$ \\
Greece & $148(75.9)$ & $47(24.1)$ & $195(100.0)$ \\
Italy & $507(75.5)$ & $165(24.5)$ & $672(100.0)$ \\
Portugal & $212(82.5)$ & $45(17.5)$ & $257(100.0)$ \\
Total & $1.169(73.7)$ & $418(26.3)$ & $1.587(100.0)$ \\
\hline
\end{tabular}

Note: Pearson $\mathrm{chi}^{2}(3)=28.9091, p=0.000$. 
TABLE 6.4 The determinants of Belgian candidates' campaigning style, B(se) ${ }^{\text {sig }}$

\begin{tabular}{|c|c|c|}
\hline & (1) & (2) \\
\hline & Personal campaign resources & Primary aim of campaign \\
\hline \multicolumn{3}{|l|}{ Party-level variables } \\
\hline Party ideology & $0.117(0.032) * *$ & $-0.146(0.091)$ \\
\hline Far-right party & $-0.955(0.404) *$ & $1.014(0.674)$ \\
\hline Inclusiveness: non-exclusive & $0.035(0.106)$ & $0.276(0.204)$ \\
\hline Centralization: centralized & $0.306(0.234)$ & $0.453(0.390)$ \\
\hline Party magnitude & $0.106(0.023) * * *$ & $-0.201(0.069)^{*}$ \\
\hline \multicolumn{3}{|l|}{ Individual-level variables } \\
\hline Incumbency local office & $0.270(0.185)$ & $-0.434(0.405)$ \\
\hline Incumbency party office & $-0.013(0.192)$ & $-0.890(0.531)$ \\
\hline Eligible list position & $1.055(0.242) * * *$ & $-0.575(0.611)$ \\
\hline Ideological congruence & $0.115(0.088)$ & $-0.159(0.165)$ \\
\hline \multicolumn{3}{|l|}{ Control variables } \\
\hline Gender: male & $0.096(0.080)$ & $-0.285(0.261)$ \\
\hline Education: university degree & $0.000(0.146)$ & $-0.792(0.259) * *$ \\
\hline Age & $-0.004(0.011)$ & $0.019(0.010)^{\wedge}$ \\
\hline _cons & $1.981(0.523)^{* *}$ & $8.242(0.503)^{* * *}$ \\
\hline $\mathrm{N}$ & 172 & 178 \\
\hline $\mathrm{R}^{2}$ & 0.301 & 0.256 \\
\hline
\end{tabular}

Note: Standard errors are clustered at the party level. ${ }^{\wedge} p<0.1,{ }^{*} p<0.05,{ }^{* *} p<0.01,{ }^{* * *} p<0.001$.

the focus on their own image rather than the party's. Results indicate that several party-level variables have an influence on candidates' campaign resources. The more rightist the ideology of candidates' party, the more personal campaigning tools candidates use. However, candidates running for a far-right party are less likely to use several personal campaigning resources compared to other candidates. This is neatly in line with our expectations (H1), and the effect is particularly important when it comes to a far-right party ideology. Then we do not find a significant impact of candidate selection methods on the outcome variable (H2). Our third hypothesis (H3) suggested a link between party size and candidates' independence that seems to be confirmed: the higher the number of seats won by the party in the constituency, the more likely it is that candidates used a larger set of personal campaigning resources.

Considering individual-level variables, we see that incumbency either in local or party office does not significantly affect candidates' use of personal campaign resources. We need to reject our fourth hypotheses ( $\mathrm{H} 4 \mathrm{a}$ and $\mathrm{H} 4 \mathrm{~b})$. Our results then show that candidates occupying a hopeful list position are more likely to use a diverse set of personal campaigning resources than other candidates, which is in line with our fifth hypothesis (H5). Finally, we do not see any significant relationship between candidates' congruence with their party and their likelihood to break free from the party in terms of personal campaign resources (H6). 
The second linear regression model uses candidates' primary aim of the campaign as dependent variable. Higher values on the dependent variable indicate that candidates aimed to attract more attention to the party than to themselves during the campaign. This model somehow brings similar results as the first model when we analyze the direction of the coefficients; however, only a few of our independent variables show to have a statistically significant effect on the outcome variable. At the party level, only party magnitude appears to have a statistically significant effect on candidates' conception of the primary aim of the campaign. Results indicate that the higher the party magnitude, the less likely it is that candidates conceive the aim of the campaign as promoting the party. This confirms our third hypothesis (H3). None of our individual-level variables seem to significantly explain candidates' conception of the primary aim of the campaign. Considering the control variables, the level of education and candidates' age do, however, matter for the aim of the campaign. The less educated and the older candidates favored the party more than themselves during their campaign.

We now turn to the determinants of candidates' representational style. Results depicted in Table 6.5 highlight the determinants of candidates' likelihood to conceive their role as that of a party delegate. Results of this model are, however, disappointing in terms of statistical significance since none of our independent variables have a statistically significant relationship with the outcome variable. Besides, the pseudo $\mathrm{R}^{2}$ indicates that the proportion of the variance explained by the model is really low (about 4\%).

\subsection{Discussion and conclusion}

The goal of this chapter was to assess whether Belgian candidates stand out in the partitocratic context of Belgian politics. Given the supremacy of Belgian political parties on a variety of matters, one would expect electoral candidates not to be able or entitled to break free from their own party. Are candidates allowed to portray themselves individually by using personal campaign resources like a personal website or conducting individual meetings at home? To what extent do candidates report having run a campaign centered on themselves rather than on their party? Do they expect to always follow the party official position when acting as representatives? Based on a large international candidate survey (CCS), we investigated these questions and mapped out two main elements.

First, we compared Belgian candidates and their counterparts in other partitocratic regimes to evaluate Belgium's exceptionalism. We assessed that Belgian candidates differ from their Greek, Italian, and Portuguese counterparts but not always in the same direction. The party grip in terms of the forecasted loyalism in parliament is stronger in Belgium compared to the other partitocratic countries, while the leeway for Belgian candidates is relatively large when it comes to campaigning style. Belgium thus appears to be exceptional among 
TABLE 6.5 The determinants of Belgian candidates' representational style, $\mathrm{B}(\mathrm{se})^{\text {sig }}$

\begin{tabular}{lc}
\hline & Representational style: party delegate \\
\hline Party-level variables & \\
Party ideology & $-0.097(0.138)$ \\
Far-right party & $0.930(1.212)$ \\
Inclusiveness: nonexclusive & $-0.045(0.408)$ \\
Centralization: centralized & $-0.583(0.436)$ \\
Party magnitude & $0.114(0.070)$ \\
Individual-level variables & \\
Incumbency local office & $-0.056(0.286)$ \\
Incumbency party office & $1.462(0.896)$ \\
Eligible list position & $0.416(0.555)$ \\
Ideological congruence & $0.124(0.197)$ \\
Control variables & \\
Gender: male & $0.060(0.270)$ \\
Education: university degree & $-0.110(0.331)$ \\
Age & $-0.014(0.011)$ \\
cons & $-0.116(0.824)$ \\
Pseudo $\mathrm{R}^{2}$ & 175 \\
\hline
\end{tabular}

Note: Standard errors are clustered at the party level. ${ }^{\wedge} p<0.1,{ }^{*} p<0.05,{ }^{*} p<$ $0.01, * * * p<0.001$.

partitocratic regimes when it comes to behavior in parliament but not in terms of campaigning style. Party discipline is deeply entrenched in would-be politicians' minds.

Second, we strived to explain the determinants of Belgian candidates' independence toward their party. Our regression models show that a series of party and individual variables matter to explain whether a given candidate will stand out. Yet, we find explanations for campaign-related models and not so much for the model uncovering representational style. Our findings demonstrate a propensity to behave independently in rightist parties (but not in radical right ones), when the party is more successful in terms of number of seats in a constituency, and also among candidates on hopeful list positions.

What our results display is a certain degree of heterogeneity, both between and within countries. There are clearly cross-country variations, so that we cannot say that all partitocratic regimes function the same. Every country is kind of exceptional in its own way. The partitocratic power might translate differently from one partitocracy to the other. In Belgium, it is party discipline in parliament that seems to be prevalent over a party-driven mode of campaign. We also conclude that within Belgium, the story varies. Although Belgium is considered a system where parties are extremely powerful, the same mechanisms do not play in all contexts. We importantly uncover party differences along their ideology and size. We also find differences between 
the candidates depending on their electoral security. One therefore cannot assert that all parties in a partitocratic regime hold a strong control over their folks, and not all candidates are in the same boat. Some take or receive more freedom to cultivate a personal vote while others remain under the thumb of their party.

\section{References}

André, A., Depauw, S., Shugart, M. S., \& Chytilek, R. (2017). Party Nomination Strategies in Flexible-List Systems: Do Preference Votes Matter? Party Politics 23(15): 589-600.

André, A., Wauters, B., \& Pilet, J. B. (2012). It's Not Only About Lists : Explaining Preference Voting in Belgium. Journal of Elections, Public Opinion and Parties 22(3): 293-313.

Aylott, N., Blomgren, M., \& Bergman, T. (2013). Political Parties in Multi-Level Polities. In The Nordic Countries Compared. London: Palgrave Macmillan.

Balmas, M., Rahat, G., Sheafer, T., \& Shenhav, R. S. (2014). Two Routes to Personalized Politics: Centralized and Decentralized Personalization. Party Politics 20(1): 37-51.

Carey,J. M. (2007). Competing Principals, Political Institutions, and Party Unity in Legislative Voting. American Journal of Political Science 51(1): 92-107.

Carey, J. M., \& Shugart, M. S. (1995). Incentives to Cultivate a Personal Vote: A Rank Ordering of Electoral Formulas. Electoral Studies 14(4): 417-439.

Close, C. (2018). Parliamentary Party Loyalty and Party Family: The Missing Link? Party Politics 24(2): 209-219.

Close, C., \& Nuñez, L. (2016). At the Root of Parliamentary Party Cohesion: The Role of Intraparty Heterogeneity and Party Ideology. Les Cahiers du Cevipol 2016(1): 2-36.

Coffé, H., \& Reiser, M. (2018). Political Candidates'Attitudes towards Group Representation. Journal of Legislative Studies 24(3): 272-297.

Cordero, G., \& Coller, X. (2015). Cohesion and Candidate Selection in Parliamentary Groups. Parliamentary Affairs 68(3): 592-615.

Dassonneville, R. (2018). ElectoralVolatility and Parties' Ideological Responsiveness. European Journal of Political Research 57(4): 1-21.

de Visscher, C. (2004). La Relation entre l'Autorité Politique et la Haute Administration. Ghent: Academia Press.

Dewachter, W. (2002). De Mythe van de Parlementaire Democratie. Leuven: Acco.

De Winter, L. (2002). Political Corruption in Belgium. In M. Bull, \& J. Newell (Eds.), Corruption in Contemporary Politics. London: Macmillan, pp. 93-105.

De Winter, L., \& Dumont, P. (2000). PPGs in Belgium: Subjects of Partitocratic Dominion. In K. Heider, \& R. Koole (Eds.), Parliamentary Party Groups in European Democracies. Political Parties behind Closed Doors. London: Routledge, pp. 106-129.

De Winter, L., \& Dumont, P. (2006). Do Belgian Parties Undermine the Democratic Chain of Delegation? West European Politics 29(5): 957-976.

De Winter, L., della Porta, D., \& Deschouwer, K. (1996a). Comparing Similar Countries. Res Publica 38: 215-236.

De Winter, L., della Porta, D., \& Deschouwer, K. (1996b). The Italo-Belgian Partitocratic Type Compared to Fourteen West-European Countries. In Annual Meeting of the American Political Science Association, San Francisco.

Enyedi, Z., \& Linek, L. (2008). Searching for the Right Organization: Ideology and Party Structure in East-Central Europe. Party Politics 14(4): 455-477.

Gauja, A. (2010). Political Parties and Elections: Legislating for Representative Democracy. Surrey and Burlington,VT: Ashgate Publishing. 
Grofman, B. (2005). Comparisons among Electoral Systems: Distinguishing between Localism and Candidate-Centered Politics. Electoral Studies 24: 735-740.

Hazan, R. Y. (2014). Candidate Selection: Implications and Challenges for Legislative Behaviour. In S. Martin, T. Saalfeld, \& K. W. Strøm (Eds.), Oxford Handbook of Legislative Studies. Oxford: Oxford University Press, pp. 108-126.

Hazan, R. Y., \& Rahat, G. (2010). Democracy within Parties: Candidate Selection Methods and Their Political Consequences. Oxford: Oxford University Press.

Hobolt, S. B., \& Tilley, J. (2016). Fleeing the Centre: The Rise of Challenger Parties in the Aftermath of the Euro Crisis. West European Politics 39(5): 971-991.

Janssen, C., Chiru, M., \& De Winter, L. (2018). Between Parties and Voters: Candidates' Role Conception in the Belgian Partitocracy. In A.Vandeleene, L. De Winter, \& P. Baudewyns (Eds.), Candidates, Parties and Voters in the Belgian Partitocracy. London: Routledge, pp. 313-339.

Karvonen, L. (2010). The Personalisation of Politics: A Study of Parliamentary Democracies. Colchester: ECPR Press.

Katz, R. S. (2001). The Problem of Candidate Selection and Models of Party Democracy. Party Politics 7(3): 277-296.

Key,V. O. (1964). Politics, Parties and Pressure Groups. 5th ed. New York, NY: Crowell.

Kristjánsson, S. (1998). Electoral Politics and Governance: Transformation of the Party System in Iceland, 1970-1996. In P. Pennings, \& J.-E. Lane (Eds.), Comparing Party System Change. London: Routledge.

Lesschaeve, C. (2017). Whose Democracy Is It ? A Study of Inequality in Policy Opinion Congruence between Privileged and Underprivileged Voters in Belgium. Antwerp: Universiteit Antwerpen.

Mair, P. (2013). Ruling the Void:The Hollowing of Western Democracy. London:Verso.

Mazzoleni, O., \& Voerman, G. (2016). Memberless Parties: Beyond the Business-Firm Party Model? Party Politics 23(6): 783-792.

Mudde, C. (2007). Populist Radical Right Parties in Europe. Cambridge: Cambridge University Press.

Rahat, G., \& Kenig, O. (2018). Party Change and Political Personalization. Oxford: Oxford University Press.

Renwick, A., \& Pilet, J.-B. (2016). Faces on the Ballot:The Personalization of Electoral Systems in Europe. Oxford: Oxford University Press.

Rihoux, B., \& Frankland, E. G. (2008). Conclusion: The Metamorphosis of AmateurActivist Newborns into Professional-Activist Centaurs. In E. G. Frankland, P. Lucardie, \& B. Rihoux (Eds.), Green Parties in Transition: The End of Grassroots Democracy? Farnham: Ashgate Publishing, pp. 259-288.

Shugart, M. S.,Valdini, M. E., \& Suominen, K. (2005). Looking for Locals:Voter Information Demands and Personal Vote-Earning Attributes of Legislators under Proportional Representation. American Journal of Political Science 49(2): 437-449.

Steyvers, K. (2014).Van Ankerpunt tot Leeg Schip: De Evolutie van Politieke Partijen. In C. Devos (Ed.), België \# 2014: Een Politieke Geschiedenis van Morgen. Ghent: Borgerhoff \& Lamberigts, pp. 115-143.

Strøm, K. W. (1997). Rules, Reasons and Routines: Legislative Roles in Parliamentary Democracies. Journal of Legislative Studies 3: 155-174.

Talshir, G. (2002). The Political Ideology of Green Parties: From the Politics of Nature to Redefining the Nature of Politics. Basingstoke: Palgrave Macmillan.

Tavits, M. (2009). The Making of Mavericks: Local Loyalties and Party Defection. Comparative Political Studies 42(6): 793-815. 
van Haute, E. et al. (2013). Party Members in a Pillarised Partitocracy. An Empirical Overview of Party Membership Figures and Profiles in Belgium. Acta Politica 48(1): 68-91.

Vandeleene, A., Dodeigne, J., \& De Winter, L. (2016). What Do Selectorates Seek? A Comparative Analysis of Belgian Federal and Regional Candidate Selection Processes in 2014. American Behavioral Scientist 60(7): 889-908.

Zittel,T., \& Gschwend,T. (2008). Individualised Constituency Campaigns in Mixed-Member Electoral Systems: Candidates in the 2005 German Elections. West European Politics 31(5): 978-1003. 